combination and the alteration of restriction patterns. It has also been suggested that the inverted repeat found in most plastomes may suppress recombinations or that plastome mutations may be corrected by gene conversions (for review see Palmer, 1985).

The large amounts of variation observed in the mtDNA of Vaccinium indicate that breeders fortuitously selected variable cytoplasms in creating highbush cultivars. This is not surprising, since three divergent species at two ploidy levels are represented. It is not known if these DNA variations translate into functional differences, but the high degree of mtDNA variability among the different cytoplasmic sources suggest that RFLPs should provide useful information on the evolution and taxonomy of the group. Nuclear RFLPs should also aid in locating economically important traits through the development of linkage maps.

\section{Literature Cited}

Ballington, J.R. 1990. Germplasm resources available to meet future needs for blueberry cultivar improvement. Fruit Var. J. 44:54-63.

Draper, A.D., J.R. Ballington, and G.J. Galletta. 1982. Breeding methods for improving southern tetraploid blueberries. J. Amer. Soc. Hort. Sci. 107:106-109.

Fox, T.D. and C.J. Leaver. 1981. The Zea mays mitochondrial gene coding cytochrome oxidase subunit II has an intervening sequence and does not contain TGA codons. Cell 26:315-323.

Hancock, J. and S. Krebs. 1986. Cytoplasms of highbush blueberry cultivars. Fruit Var. J. 40:4950

Hancock, J.F. and J.H. Siefker. 1986. Levels of inbreeding in highbush blueberry cultivars. HortScience 17:363-366.

Helentjaris, T., G. King, M. Slocum, C. Siedenstrang, and S. Wegman. 1985. Restriction frag ment polymorphisms as probes for plant diversity and their development as tool for applied plant breeding. Plant Mol. Biol. 5:109-118.

Helentjaris, T., M. Slocum, S. Wright, A. Schaefer, and J. Nienhuis. 1986. Construction of genetic linkage maps in maize and tomato using restriction fragment length polymorphisms. Theor. Appl. Genet. 72:761-769.

Hosaka, K. and R.F. Hanneman, Jr. 1988. The origin of the cultivated tetraploid potato based on chloroplast DNA. Theor. Appl. Genet. 76:172-176

Ichikawa, H., L. Tanno-Svenaga, and J. Imamura. 1989. Mitochondrial genome diversity among cultivars of Daucus carota (ssp. sativus) and their wild relatives. Theor. Appl. Genet. 77:39-43.

Landry, B.S., R.V. Kesseli, B. Farrara, and R.W. Michelmore. 1987. A genetic map of lettuce (Lactuca sativa L.) with restriction fragment length polymorphism, isozyme, disease resistance and morphological markers. Genetics 116:331-337

Lonsdale, D.M. 1984. A review of the structure and organization of the mitochondrial genome of higher plants. Plant Mol. Biol. 3:201-206.

Levings, C.S., III, and D.R. Pring. 1976. Restriction endonuclease analysis of mitochondrial DNA from normal and Texas cytoplasmic male-sterile maize. Science 193:158-160.

Lyrene, P.M. 1990. Low-chill highbush blueberries. Fruit Var. J. 44:82-87.

Maniatis, T., E.F. Fritsche, and J. Sambrook. 1982 Molecular cloning-A laboratory manual. Cold
Spring Harbor Laboratory Press, Cold Spring Harbor, N.Y.

Ogihara. Y. and K. Tsunewaki. 1988. Diversitv and evolution of chloroplast DNA in Triticum and Aegilops as revealed by restriction fragment analysis. Theor. Appl. Genet. 76:321-332.

Osborn, T.C., D.C. Alexander, and J.F. Fobes. 1987. Identification of restriction fragment length polymorphism linked to genes controlling soluble solids content in tomato fruit. Theor. Appl. Genet. 73:350-356.

Palmer. J.D. 1985. Comparative organization of chloroplast genomes. Annu. Rev. Genet. 19:325354.

Phillips, A.L. 1985. Restriction map and clone bank of tomato plastid DNA. Current Genet. 10:147-152.

Rogers, S.O. and A.J. Bendich. 1985. Extraction of DNA from milligram amounts of fresh. herbarium and mummified plant tissue. Plant Mol. Biol. 5:69-76.

Schumann, C. and J. Hancock. 1989. Paternal inheritance of plastids in alfalfa. Theor. Appl. Genet. 78:863-866.

Southern, E.M. 1975. Detection of specific sequences among DNA fragments separated by gel electrophoresis. J. Mol. Biol. 98:503-517.

Thomashow, M.F., V.C. Knauf, and E.W. Nester. 1981. Relationship between the limited and wide host range octopine-type $\mathrm{Ti}$ plasmids of Agrobacterium tumefaciens. J. Bacterial. 146:484-493.

Timothy, D.H., C.W. Levings, III, D.R. Pring, M.F. Conde. and J.L. Kermickle. 1979. Organelle DNA variation and systematic relationships in the genus Zea: Teosinte. Proc. Natl. Acad. Sci. USA 76:4220-4224.

Wagner, D.B., G.R. Furnier, M.A. Saghai-Maroof, S.M. Williams, B.P. Dancik, and R.W. Allard. 1987. Chloroplast DNA polymorphisms in lodgepole and Jack pines and their hybrids. Proc. Natl. Acad. Sci. USA 84:2097-2100.

Weissinger, A.K., D.H. Timothy, C.S. Leving, III, and M.M. Goodman. 1983. Pattern of mitochondrial DNA variation in indigenous maize races of Latin America. Genetics 10:365-379.

Wight, C.P., D.T. Dennis, and R.H. Lau. 1986 A rapid and efficient method to remove labeled molecular probes from nucleic acids immobilized on solid supports. Mol. Biol. Rpt. 11:173175.

HORTSCIENCE 27(1):47-50. 1992.

\title{
Spontaneous Tetraploid Melons
}

\section{Perry E. Nugent}

U. S. Vegetable Laboratory, Agricultural Research Service, U. S. Department of Agriculture, Charleston, SC 29414

\section{Dennis T. Ray ${ }^{2}$}

Department of Plant Sciences, University of Arizona, Tucson, AZ 85721

Additional index words. muskmelon, cantaloupe, Cucumis melo, polyploidy, virescent marker, diploid, triploid, seedless melons

Abstract. Since 1968, three spontaneous 4x melons (Cucumis melo L.) plants were discovered in our field or greenhouse plantings. Two were found in the cultivar Planters Jumbo and one in the virescent marker C879-52. Each of these $4 x$ plants had rounded cotyledons, shorter internodes, thicker stems and leaves, more hairs, and smaller fruits, with larger stem and blossom scars, than their $2 x$ counterparts. Also, their flowers, pollen grains, stomates, and seeds were larger. The discovery of a $4 x$ virescent plant in 1987 allows easier germplasm transfer between ploidy levels. Morphological characteristics of $2 x$ and $4 x$ melons will allow identification without need for chromosome counts.

Interest in tetraploid $(4 \mathrm{x}=48$ chromosomes) melons began in the 1930s with the discovery that colchicine produced polyploid plants. Shifriss (1942) began developing tetraploids of Cucumis sativus L. with colchicine in 1939 and then produced tetraploids of C. melo L. Batra (1952) developed six 4x melon cultivars with colchicine. Fruit quality in these tetraploids was superior to diploids ( $2 \mathrm{x}=24$ chromosomes); however, yields were lower in five of the six $4 \mathrm{x}$ lines. The $4 \mathrm{x}$ plants had larger flowers, pollen grains,

Received for publication 10 Dec. 1990. The cost of publishing this paper was defrayed in part by the payment of page charges. Under postal regulations, this paper therefore must be hereby marked advertisement solely to indicate this fact.

${ }^{1}$ Research Horticulturist.

${ }^{2}$ Assistant Professor. and stomates in addition to thicker stems and lower fertility than the $2 \mathrm{x}$ plants. Tetraploid fruit were smaller and rounder than diploid fruit. Kubicki (1962) developed 4x cucumbers and melons and stated that spontaneous 4x types were lacking in the genus Cucumis. Dumas de Vaulx (1974) induced 4x with colchicine, studied fertility, and confirmed the morphological characteristics described by previous workers. He found that pollen tube growth was normal and did not cause poor seed set in self-pollinated $4 \mathrm{x}$ or crosses between $2 \mathrm{x}$ and $4 \mathrm{x}$ plants. A few viable seeds were obtained when the $4 \mathrm{x}$ parent was female and none when it was male. Ervin (1941) studied polysomaty in C. melo. He found that $4 \mathrm{x}$ cells occur regularly in root and stem tips of most plants. This finding suggested that polysomaty may also occur in gametes and that spontaneous $4 \mathrm{x}$ plants might be 
Table 1. Ploidy of plants with easily recognizable $2 x$ or $4 x$ visual traits.

\begin{tabular}{|c|c|c|c|c|c|c|c|c|}
\hline \multirow[b]{2}{*}{ Line } & \multirow[b]{2}{*}{$\begin{array}{l}\text { No. } \\
\text { plants }\end{array}$} & \multicolumn{6}{|c|}{ External visual traits } & \multirow[b]{2}{*}{$\begin{array}{l}\text { Confirmed } \\
\text { ploidy }\end{array}$} \\
\hline & & Seed & Cotyledon & Stem & Flower & $\begin{array}{l}\text { Stcm } \\
\text { scar }\end{array}$ & $\begin{array}{c}\text { Blossom } \\
\text { scar }\end{array}$ & \\
\hline \multicolumn{9}{|l|}{ Diploids } \\
\hline C879-J2 & 6 & Long & Long & Thin & Small & Small & Small & $2 \mathrm{x}$ \\
\hline Planters Jumbo & 14 & Long & Long & Thin & Small & Small & Small & $2 x$ \\
\hline \multicolumn{9}{|l|}{ Putative tetraploids } \\
\hline $\mathrm{C} 883-\mathrm{m} 6$ & 4 & Plump & Round & Thick & Large & Large & Large & $4 x$ \\
\hline $67-1-100$ & 8 & Plump & Round & Thick & Large & Large & Large & $4 x$ \\
\hline C879-J2-H10 & 8 & Plump & Round & Thick & Large & Large & Large & $4 \mathrm{x}$ \\
\hline
\end{tabular}

found. Love et al. (1986) reported that $\approx 0.02 \%$ doubled gametes occur in watermelon. These gametes occasionally result in the development of spontaneous $4 x$ plants. A similar percentage of doubled gametes may occur in other melons.

C.F. Andrus (unpublished, 1961), U.S. Vegetable Lab., Charleston, S.C., found that $4 \mathrm{x}$ melons had better flesh quality and higher levels of resistance than $2 \mathrm{x}$ melons. $\mathrm{He}$ also believed that they had many shortcomings and were not very useful (personal communication). During his study, he developed several colchicine-derived $4 x$ plants. He also found a few spontaneous $4 \mathrm{x}$ melon plants in field plots. One spontaneous $4 \mathrm{x}$ plant from 'Planters Jumbo', designated C883-m6, was saved for further study. In 1969, P.E.N. found another 4x 'Planters Jumbo' plant in a greenhouse planting of 67-1-m6. This $4 \mathrm{x}$ selection
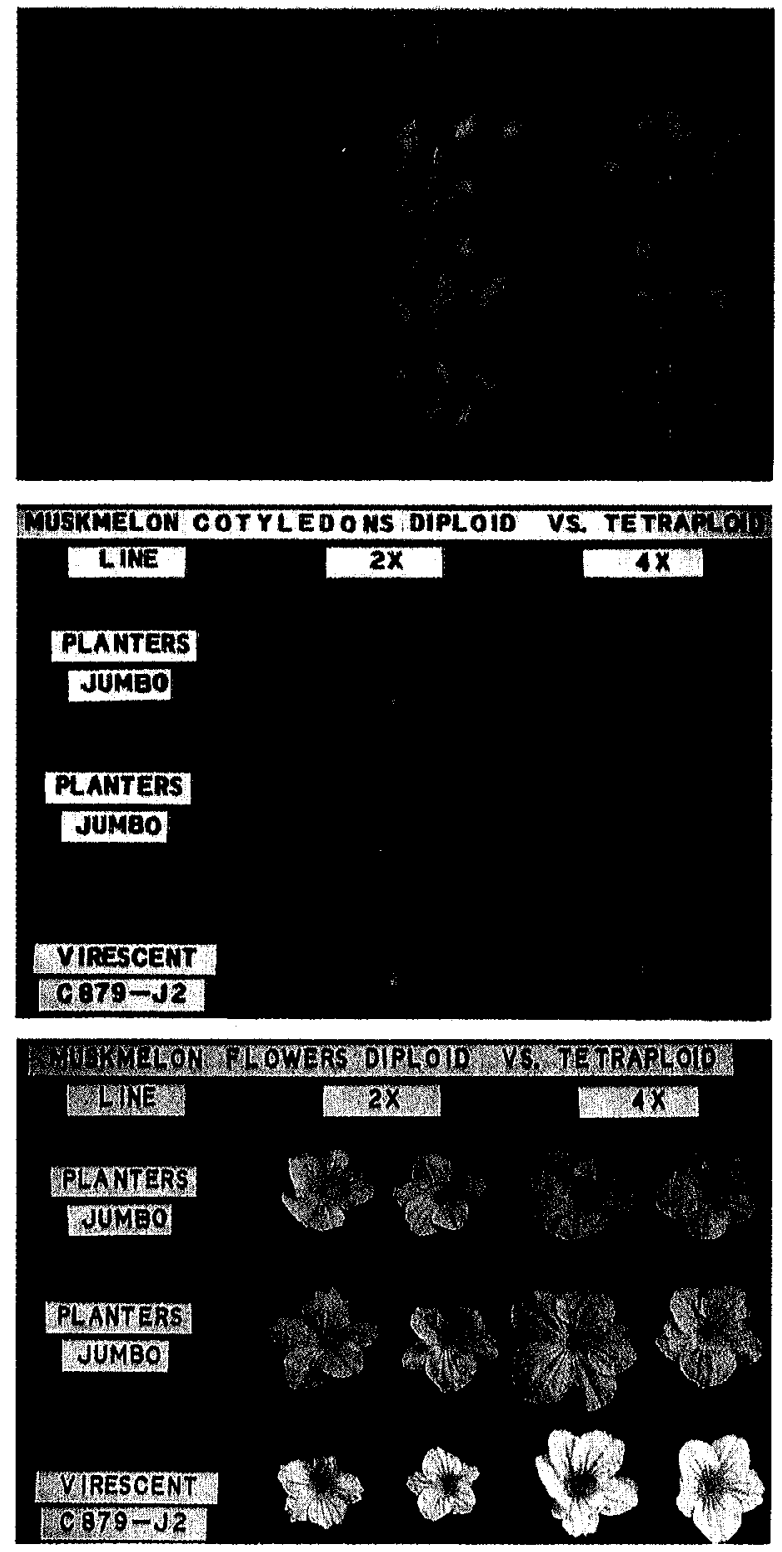

Fig. 1. A comparison of $2 \mathrm{x}$ and $4 \mathrm{x}$ melon seed (top), cotyledons (center), and flowers (bottom).

was designated 67-1-m6-100. After considerable study, we concluded that $4 \mathrm{x}$ melons were no better than current $2 \mathrm{x}$ cultivars and discontinued the project.

The project was revived in 1983 in response to requests from industry for information and photographs of $4 \mathrm{x}$ melons. They also asked about the availability of $4 \mathrm{x}$ germplasm and the possibility of producing seedless melons. We increased the 1969 seed lots and re-examined plant and fruit characteristics. Our objectives were to 1 ) document the occurrence of two spontaneous $4 \mathrm{x}$ lines in our collection; 2) compare their distinguishing characteristics with those of artificially produced $4 \mathrm{x}$ lines; 3 ) devise techniques for developing $4 \mathrm{x}$ virescent marker plants to use in the production of more diverse $4 \mathrm{x}$ melon germplasm; and 4) present photographs that will make it easier to recognize tetraploid melons in the future.

The plant materials for this study included 'Planters Jumbo' and its two 4x progeny mentioned above. Also included were C87952 (Nugent, 1987) plus a spontaneous $4 \mathrm{x}$ plant (C879-J2-H10) discovered in a 1987 field planting of this virescent $(v v)$ marker. This plant had thick leaves, short internodes, and four small, round to oblate fruit with large stem and blossom scars. Because of its $4 x$ characteristics, the fruit were harvested. These fruit contained many hollow and 35 large, thick, plump seed. Twenty of these seeds were planted in the greenhouse to study the morphology of the resulting plants and to pollinate some of them. Self-pollinations were successfully made on eight of 10 plants. Seven of these selfed plants had $4 \mathrm{x}$ characteristics, but one appeared to be $2 \mathrm{x}$. The two remaining plants did not set fruit. One of these two plants had typical $4 \mathrm{x}$ characteristics. The other was smaller with short internodes, thick and curled leaves, and flowers with leafy sepals but no petals. Its male flowers had no anthers and aborted at opening. This plant, which did not survive, resembled the octaploid (8x) described by Kubicki (1962).

These three 4x lines (C883-m6, 67-1-m6, C 879-J2-H10) were identified as tetraploids based on descriptions by Batra (1952) and Kubicki (1962) and phenotypic similarity to colchicine-produced tetraploids developed at this laboratory in the late 1960s. We now present observations on the morphology and cytology of these three spontaneous $4 \mathrm{x}$ C. melo plants, document the occurrence of spontaneous tetraploid melons, and provide a visual guide simplifying the identification of $4 \mathrm{x}$ melon plants and fruit. 
Table 2. Fruit diameter and weight of confirmed $2 x$ and $4 x$ melons.

\begin{tabular}{|c|c|c|c|c|c|c|c|}
\hline \multirow[b]{2}{*}{ Line } & \multirow[b]{2}{*}{ Ploidy } & \multirow[b]{2}{*}{ No. plants } & \multirow[b]{2}{*}{ No. fruit } & \multicolumn{2}{|c|}{ Diam $(\mathrm{cm})$} & \multicolumn{2}{|c|}{ Wt (g) } \\
\hline & & & & Range & Mean & Range & Mean \\
\hline $\mathrm{C} 879-\mathrm{J} 2$ & $2 x$ & 6 & 9 & $12.6-18.3$ & 14.1 & $1045-1852$ & 1499 \\
\hline $\mathrm{C} 879-\mathrm{J} 2-\mathrm{H} 10$ & $4 x$ & 8 & 26 & $10.1-14.6$ & 12.6 & $610-1490$ & 995 \\
\hline \multicolumn{8}{|l|}{ Planters } \\
\hline Jumbo & $2 x$ & 14 & 14 & $14.0-20.3$ & 15.4 & $1575-3240$ & 2383 \\
\hline $\mathrm{C} 883-\mathrm{m} 6$ & $4 x$ & 4 & 18 & $8.9-15.5$ & 14.1 & $460-1953$ & 1485 \\
\hline $67-1-100$ & $4 x$ & 8 & 8 & $13.3-15.2$ & 14.5 & $960-1850$ & 1303 \\
\hline
\end{tabular}

Seeds were started in sand beds or peat pellets. Pollinations were made on plants grown to maturity in $370-\mathrm{cm}^{3}$ pots or soil benches in the greenhouse. Standard hand- pollination procedures were used. Photographs of fruit were from plants grown on raised, paper-mulch-covered beds. These beds, fertilized at a rate of $454 \mathrm{~kg}$ of $5 \mathrm{~N}$ -
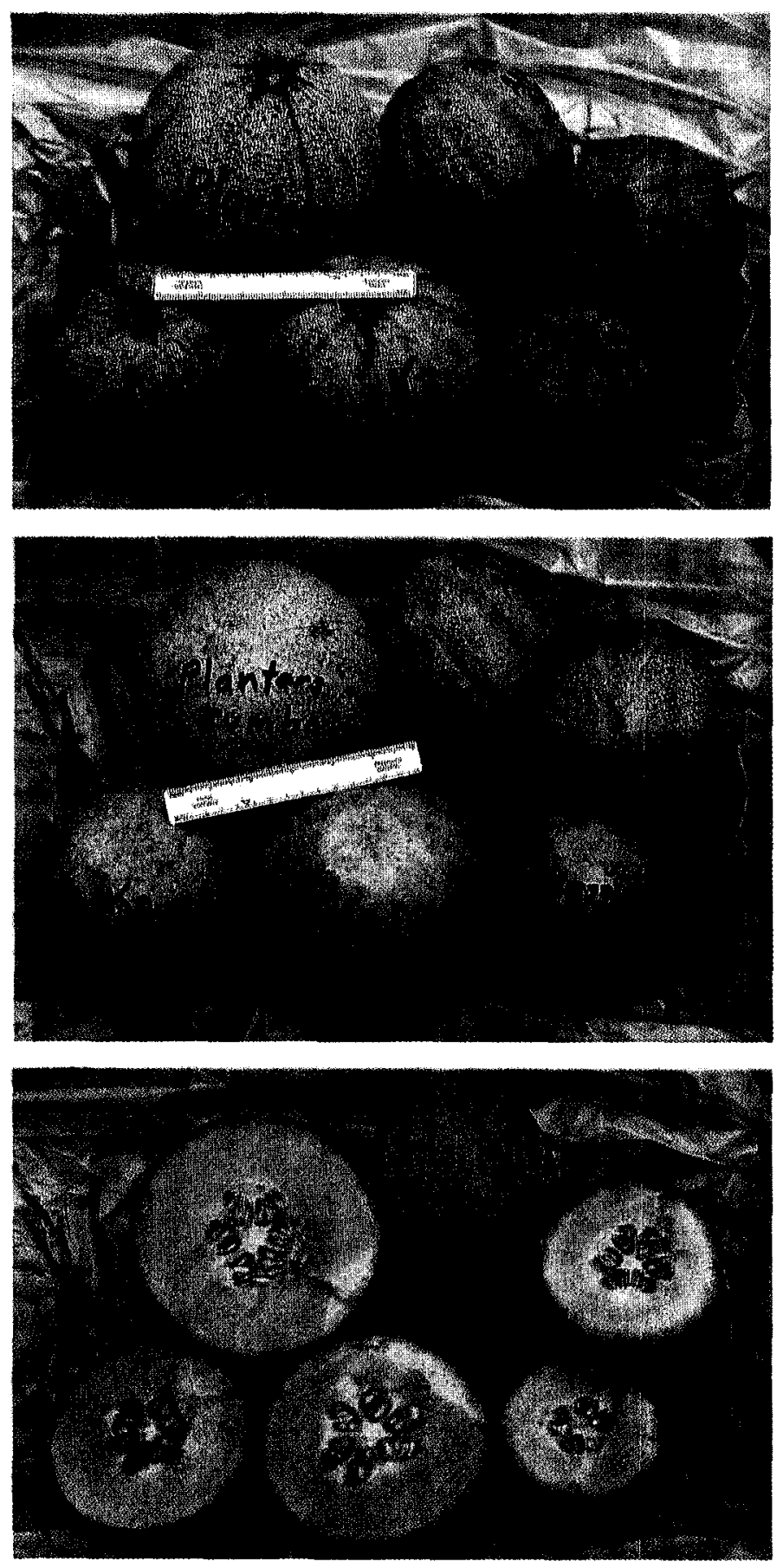

Fig. 2. Stem (top) and blossom (center) scars and cross-sections (bottom) of $2 \mathrm{x}$ 'Planters Jumbo' and $\mathrm{C} 879-\mathrm{J} 2$ (top row) and 4x melons (bottom row) C883-m6 (K2), 67-1-m6-100 (K3), and $\mathrm{C} 879$. $\mathrm{J} 2-\mathrm{H} 10$.

4.4P-8.3K/ha, were $200 \mathrm{~cm}$ apart in field plots isolated at least $150 \mathrm{~m}$ from other melons. No irrigation or pesticides were used on these plants.

Ploidy of all plants in this study, determined by visual morphological traits, was confirmed by chromosome counts. This demonstrated that visual traits are useful in identifying various ploidy levels (Table 1). A single descriptive term was used instead of measurements to simplify recognition of plants at each ploidy level. Flower buds for cytological ploidy level confirmation were fixed in Carnoy's solution (6 ethyl alcohol : 3 chloroform : 1 glacial acetic acid) or a modification (4 chloroform : 3 ethyl alcohol $: 1$ glacial acetic acid), refrigerated at $4 \mathrm{C}$ for 24 to $48 \mathrm{~h}$, and then placed in $70 \%$ alcohol. Anthers from squashes of fixed buds were prepared in acetocarmine for chromosome counts.

The spontaneous $4 \mathrm{x}$ plants had more rounded cotyledons, shorter internodes, thicker leaves, more trichomes, and smaller fruits with larger stem and blossom scars than their $2 x$ counterparts (Figs. 1 and 2). Also, their flowers, pollen grains, stomates, and seeds were larger. Many of the characteristics of these spontaneous $4 \mathrm{x}$ plants were similar to colchicine-produced lines. For example, all $4 x$ plants in this experiment had smaller fruit, set fewer seed, and seemed less fertile than their 2x parents (Tables 2 and 3). Several colchicine-induced $4 x$ plants from C.F. Andrus were similar in many ways to the three spontaneous lines described in this paper, but their quality was not as good. Illustrations of these tetraploids are provided to guide breeders in identifying $4 x$ plants during early growth and at harvest (Figs. 1 and 2). Chromosome counts of 'Planters Jumbo' and its $4 \mathrm{x}$ progeny illustrate confirmed ploidy levels (Fig. 3).

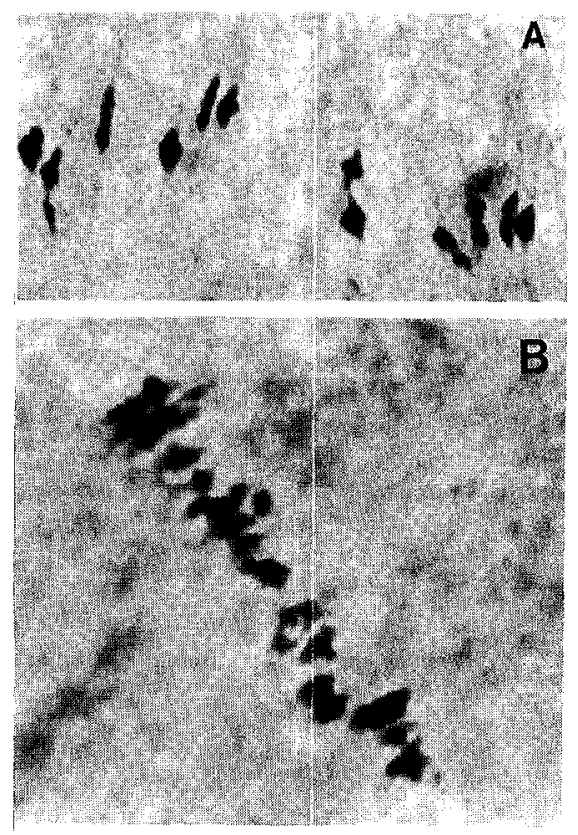

Fig. 3. Chromosomes of $2 x(A)$ and $4 x(B)$ 'Planters Jumbo'. 
Table 3. Seed counts and weights of confirmed $2 x$ and $4 x$ melons.

\begin{tabular}{|c|c|c|c|c|c|c|c|}
\hline \multirow[b]{2}{*}{ Line } & \multirow[b]{2}{*}{ Ploidy } & \multirow[b]{2}{*}{ No. plants } & \multirow[b]{2}{*}{ No. fruit } & \multicolumn{2}{|c|}{ No. seed/fruit } & \multicolumn{2}{|c|}{ Total seed wt $(g)$} \\
\hline & & & & Range & Mean & Range & Mean \\
\hline C879-J2 & $2 x$ & 6 & 9 & $279-571$ & 417.6 & $8.3-16.3$ & 12.7 \\
\hline $\begin{array}{l}\text { C879-J2-H10 } \\
\text { Planters }\end{array}$ & $4 x$ & 8 & 26 & $15-305$ & 94.5 & $0.5-4.4$ & 2.0 \\
\hline Jumbo & $2 \mathrm{x}$ & 14 & 14 & $338-716$ & 496.9 & $6.6-21.4$ & 14.5 \\
\hline C883-m6 & $4 x$ & 4 & 18 & $45-229$ & 116.5 & $0.9-5.5$ & 2.9 \\
\hline $67-1-100$ & $4 x$ & 8 & 8 & $24-179$ & 89.1 & $0.5-5.3$ & 2.3 \\
\hline
\end{tabular}

Fast and accurate visual identification of $4 \mathrm{x}$ plants, without measurements, is essential to the development of commercially useful lines. By using characteristics such as those described and illustrated, accurate identification of $4 \mathrm{x}$ melons is possible. This procedure reduces the need for more difficult and time-consuming chromosome counts. Ail three $4 \mathrm{x}$ lines reported will be useful in improving this germplasm and the development of new germplasm sets. As new lines are identified, they can be tested for potential use in the development of inbred lines, hy- brids, or parents for the production of triploid (3x) hybrids. likely will be especially useful as a female for production of $3 \mathrm{x}$ and $4 \mathrm{x}$ germplasm. It will be particularly helpful in large, fieldscale research and commercial seed production without hand pollination. With this technique, all hybrid seedlings from $4 \mathrm{x}$ virescent plants will be normal green, in contrast to parental-type yellow seedlings having the recessive virescent trait. Initial attempts to cross $4 \mathrm{x}$ melon plants with $2 \mathrm{x}$ plants have
The recently discovered $4 \mathrm{x}$ virescent line thus far resulted in fruit with hollow seedcoats in the first generation and no 3x plants.

\section{Literature Cited}

Batra, S. 1952. Induced tetraploidy in melons. J. Hered. 43:141-148.

Dumas de Vaulx, R. 1974. Étude des possibilités d'utilisation de la polyploidie dans l'amélioration du melon [ Cucumis melo L.]. Ann. Amelior. Plantes 24:389-403.

Ervin, CD. 1941. A study of polysomatry in Cucumis melo. Amer. J. Bot. 28:113-124.

Kubicki, B. 1962. Polyploidy in melons [Cucumis melo L.] and cucumbers [ Cucumis sativus L.]. Genetica Polonica 3-2:161-179.

Love, S.L., B.B. Rhodes, and P.E. Nugent. 1986. Controlled pollination transfer of a nuclear malesterile gene from a diploid to a tetraploid watermelon line. Euphytica 35:633-638.

Nugent, P.E. 1987. C879-J1 and C879-J2 virescent mutant melon breeding lines. HortScience 22:333-335.

Shifriss, O. 1942. Polyploids in the genus Cисиmis. J. Hered. 33:144-152.

HORTSCIENCE 27(1):50-51. 1992.

\title{
Field Reaction of Landrace Components of Red Mottled Beans to Common Bacterial Blight
}

\author{
James S. Beaver \\ Department of Agronomy, University of Puerto Rico, Mayaguez, \\ PR 00709 \\ James R. Steadman \\ Department of Plant Pathology, University of Nebraska, Lincoln, \\ NE 68583
}

\section{Dermot P. Coyne Department of Horticulture, University of Nebraska, Lincoln, NE 68583 \\ Additional index words. Phaseolus vulgaris, Xanthamonas campestris pv. phaseoli, germplasm, disease resistance}

\begin{abstract}
Field reaction of 25 red mottled bean ( Phaseolus vulgaris L.) genotypes to common bacterial blight [Xanthomonas campestris pv. phaseoli (Smith) Dye] was evaluated in Puerto Rico over 2 years. The average disease severity (percent leaf area with symptoms) was similar over years. The determinate red mottled genotypes had almost twice as much disease as indeterminate genotypes. Eight of the indeterminate genotypes had significantly less disease than the mean of the field experiments. These genotypes may serve as useful sources of resistance to common bacterial blight. The size of the chlorotic zone around necrotic lesions varied between growing seasons, showing that environment can influence the expression of common bacterial blight symptoms.
\end{abstract}

Common bacterial blight $(\mathrm{Cbb})$ is a serious disease in tropical and temperate bean

Received for publication 19 Feb. 1991. Research supported in part by USAID/BIFAD Bean/Cowpea CRSP grant no. AID/DSAN-XII-G-0261. The cost of publishing this paper was defrayed in part by the payment of page charges. Under postal regulations, this paper therefore must be hereby marked advertisement solely to indicate this fact. growing regions (Beaver et al., 1985; Coyne and Schuster, 1974; Schieber, 1970). Most red mottled beans grown in the Dominican Republic are susceptible to common bacterial blight, but the characteristic chlorotic border around the necrotic leaf lesions often has not been observed on certain 'Pompadour'-type red mottled genotypes. The red mottled landrace cultivars, mostly grown by small-scale farmers, have been found to vary for several important traits, including growth habit, leaf pubescence, and biological $\mathrm{N}$ fixation capacity (Catano, 1990; Oviedo et al., 1990). The possibility that disease reaction could also vary led to the objective of this research: to evaluate a group of selections from the Dominican red mottled bean landrace for necrotic and chlorotic field reaction to common bacterial blight.

Twenty-five determinate and indeterminate red mottled bean genotypes were evaluated in Puerto Rico for field reaction to common bacterial blight in 1988 and 1989 . Two red kidney genotypes, 27R and 3M152 , were also planted as susceptible controls. The experiments were planted at the Isabela Substation on 31 Oct. 1988 and 11 Oct. 1989. A randomized complete block design with five replications was used. Experimental units consisted of one 1.5-m row planted with 15 seed. Plots were evaluated for disease severity 46 days after planting in 1988 and 58 days after planting in 1989. All genotypes were at the early to mid-pod-fill stage of development when visually evaluated for percentage of leaf area showing necrosis and water-soaking due to $\mathrm{Cbb}$. In addition, the size of the chlorotic zones surrounding the $\mathrm{Cbb}$ lesions was rated using a scale where $1=$ no chlorotic zone and $5=$ a chlorotic zone surrounding and nearly as large as the necrotic lesion. Rainfall and temperatures were normal and, therefore, favorable for disease development. Natural infection on the susceptible genotypes became prominent shortly after flowering. The average disease severity was similar between years. The disease severity on the susceptible controls ranged from $24 \%$ to $34 \%$ (Table 1). The small plots with five replications provided an adequate level of precision to detect significant disease severity differences among genotypes. Moreover, the disease se- 